\title{
Foreword: Special issue on fungal grapevine diseases
}

\author{
Levente Kiss • Imre J. Holb • Vittorio Rossi • \\ Lance Cadle-Davidson • Michael J. Jeger
}

Published online: 22 December 2015

(C) Koninklijke Nederlandse Planteziektenkundige Vereniging 2015

An impressively large proportion of fungicides applied in European, North American and Australian agriculture has been used to manage grapevine powdery mildew (Erysiphe necator), grapevine downy mildew (Plasmopara viticola), and botrytis bunch rot (Botrytis cinerea). These fungal and oomycetous plant pathogens remain amongst the most important plant pathological problems worldwide, despite extensive research on pathogenesis, epidemiology and management. For example, the national economic impact of these three pathogens in Australia was estimated at \$191 million per year, more than three-fold greater than all other

L. Kiss $(\bowtie) \cdot$ I. J. Holb

Plant Protection Institute, Centre for Agricultural Research, Hungarian Academy of Sciences (MTA-ATK),

H-1525 BudapestP.O. Box 102, Hungary

e-mail: kiss.levente@agrar.mta.hu

I. J. Holb

University of Debrecen, Centre for Agricultural Sciences and Engineering, Faculty of Agronomy, H-4015 Debrecen, Hungary

V. Rossi

Department of Sutainable Crop Production, Università Cattolica del Sacro Cuore, Via E. Parmense 84, I-29122 Piacenza, Italy

L. Cadle-Davidson

USDA-ARS Grape Genetics Research Unit, NYSAES, Geneva, NY 14456, USA

M. J. Jeger

Division of Biology, Imperial College London, Silwood Park Campus, Ascot SL5 7PY, UK grapevine pests combined. ${ }^{1}$ In California, $20 \%$ by weight of all pesticides applied in the state are for one disease - grapevine powdery mildew. Managing this disease accounts for 9 to $20 \%$ of all cultural costs for grape production; in addition, there is significant pesticide exposure to farm workers and the environment. ${ }^{2}$

The vast majority of grape production relies upon the European grapevine, Vitis vinifera, which is highly susceptible to these and many other pests and diseases. Many fungal diseases of grapevine, like grape black rot (Guignardia bidwellii), cause extreme problems occasionally or regionally while grapevine trunk disease complexes, primarily of fungal origin, are serious, chronic threats in viticulture worldwide with significance that may be underestimated. In addition, a vast array of grapevine pests and pathogens, such as phylloxera aphid, crown gall, Pierce's disease, leafroll, and root-knot nematodes, have shaped the history of grape production and spurred scientific innovations. As a consequence of the above, it is not surprising that each year numerous international scientific meetings on grapevine diseases respond to the continuous need of information on how to deal with various aspects of these economically important plant pathological challenges, and circulate the new knowledge coming from the many research projects on this topic.

In spite of so many smaller and larger meetings on this issue, the first international symposium dedicated

\footnotetext{
$\overline{{ }^{1} \mathrm{http} / / / \text { research}}$.wineaustralia.com/wp-content/uploads/2014/10/ GWR-08-04-ExecSummary.pdf

${ }^{2} \mathrm{http} / / /$ vinecon.ucdavis.edu/publications/cwe1401.pdf
} 
entirely to fungal grapevine pathogens was held only recently, from 29 March to 2 April 2015, in Eger, a famous wine-producing region in Hungary. This meeting, the first International Workshop on Fungal Grapevine Diseases (http://grapedisease.uni-eger.hu/), which included the oomycete Plasmopara viticola as a 'honorary fungus', was hosted by the Eszterházy Károly University of Applied Sciences in Eger, and co-organized by the Plant Protection Institute, Centre for Agricultural Research of the Hungarian Academy of Sciences (MTA-ATK). The current Special Issue of EJPP contains both nine papers that resulted from the workshop and three other papers which have recently been submitted to the journal on this topic. We think that this Special Issue can be useful for a broad spectrum of researchers, students, academics, as well as for professionals working in the plant protection industry and extension and advisory service agencies. 